\title{
MORPHOLOGICAL STUDIES OF THE SENSORY EPITHELIA OF THE VESTIBULAR SENSORY ORGANS
}

\author{
Kozo WaTANUKI
}

\section{SUMMARY}

For studying surface areas of the vestibular sensory epithelia, the silver reaction method and succinic dehydrogenase staining were successfully used to demonstrate the over-all view of each sensory epithelium. In the central part of the sensory epithelium of the crista ampullaris, larger sensory cells were often found while in the peripheral regions, smaller sensory cells were observed as they appeared on the surface of the sensory epithelium. Cell density was greater in peripheral areas than in the central region. About two-thirds of all sensory cells in the striola were type I cells. Outside the striola, type I sensory cells included approx 45 per cent of the cells while type II was found among all the remainder. Larger sensory cells of type I which were found in the striola were usually innervated by common nerve chalices, however these cells in the striola contained more succinic dehydrogenase activity than smaller cells located both in the striola and in other peripheral areas of the macula.

\section{INTRODUCTION}

The sensory epithelium of the crista ampullaris is covered with the cupula, while that of the macula of both otolithic organs is covered with otolithic membranes and otolithic layers. Under these coverings, the sensory epithelia of the vestibular endorgans constitute a mono-cell layer consisting of sensory and supporting cells. The sensory epithelium is not uniform in structure, but differs according to parts.

Retzius (1884) ${ }^{15}$ and Iwata $(1924)^{7}$ first sketched the surface structure of the sensory epithelia of the vestibular organs in experimental animals. Lindeman $\left(1967,{ }^{11} 196912,13,14\right)$ recently studied sensory epithelia of the vestibular organs in guinea pigs by means of dissected specimens and observation using phase-contrast microscopy. Conprehensive quantitative data was thus reported.

In the present study, the silver reaction method (Watanuki 196816, Watanuki et al 196917, Katagiri et al 19689,10) and succinic dehydrogenase staining (Barka and Anderson 19631) were successfully employed for the surface study of vestibular endorgans (Watanuki et al 1971 18$)$.

\section{MATERIAL AND METHODS}

Fifty young pigmented guinea pigs, each weighing approx. $300 \mathrm{~g}$, were utilized. After

From the Department of Otolaryngology, Tohoku University School of Medicine, Sendai 
removal of the stapes and the surrounding bony walls, the membranous walls of the utricle and saccule were ruptured in distilled water. The temporal bone was then immersed in a $0.2 \% \mathrm{AgNO}_{3}$ solution for approx. $1 \mathrm{~min}$. It was then washed in distilled water for a few seconds and fixed in $10 \%$ formalin under fluorescent or day light for about $24 \mathrm{~h}$. For the succinic dehydrogenase staining, the exposed temporal bone was incubated in the following solutions for $30 \mathrm{~min}$ at a temperature of $37^{\circ} \mathrm{C}$ :

$\begin{array}{lcc}\text { Sodium succinate } & 0.06 \mathrm{M} & 2.0 \mathrm{ml} \\ \text { Nitro BT } & 0.2 \% & 5.0 \mathrm{ml} \\ \text { Phosphate buffer } & 0.2 \mathrm{M} \mathrm{(pH} \mathrm{7.4)} & 2.0 \mathrm{ml} \\ \text { Ringer's solution } & & 1.0 \mathrm{ml}\end{array}$

After a $24 \mathrm{~h}$ fixation in $10 \%$ formalin, the specimens were dissected for light-microscopic examination. Some celloidin sections were also studied after succinic dehydrogenase staining.

\section{OBSERVATIONS}

1) Maculae sacculi et utriculi: The sensory epithelium of the macula utriculi is kidney-shaped with the anterior part broader than the posterior, while that of the saccule is sickle-shaped with the anterior part curving in a superior-posterior direction ("Dorsallappen"; Burlet and Haas, 19242; Burlet and Hoffman, 19293; "Dorsalzipfel"; Werner, $1933^{19}$ ). In the sensory epithelium of the macula sacculi and utriculi, an indentation of the sensory epithelium was found, medially in the utricle, while the same indentation was observed in the superior-posterior direction of the saccule. The structure of the sensory epithelium of the macula sacculi and utriculi was, in principle, similar to that of the crista ampullaris. In the striola, the free surface of the sensory cell was usually larger than that in other parts of the sensory epithelium. Among these larger cells, a small number of sensory cells with a smaller free surface were also found. The density of the sensory cells in the striola and in the indented part of the sensory epithelium was less than in other areas. The sensory as well as the supporting cells outside the striola were arranged fan-wise radiating away from the striola. The density of the sensory cells was higher in the utricle than in the saccule. By focussing the light-microscope at various levels, the shape of the single sensory cell was followed from the surface to the bottom. The nerve chalice surrounding the type I sensory cell was thus clearly identified. In the striola, a great number of sensory cells with a large free surface were found to be wrapped in common nerve chalices. Here and there three sensory cells were found to be encircled by one nerve chalice. In the striolae of the sensory epithelia of both the macula sacculi and utriculi, about two-thirds of all the sensory cells were type I with a large free surface, while in other peripheral areas, the ratio of type I to type II was approx. 1.0 to 1.2. There were no significant differences in the sensory epithelia between the macula sacculi and utriculi with respect to the relative distribution of type I and type II. The total number of sensory cells in the vestibular sensory organ of twenty inner ears can be seen on the table herein. 
2) Crista ampullaris: The sensory epithelium covers the saddle-shaped crista, which is surrounded by the transitional epithelium on both canalicular and utricular sides, and on both lateral sides by the semilunatum epithelium. The surface specimen of the sensory epithelium of the crista posterior was rectangular in shape with a blunted corner, while that of the crista anterior and lateralis was usually trapezoid, the longitudinal axis of the utricular side being shorter than that of the canalicular side. Both the crista anterior and the crista lateralis were usually almost symmetrical in size as well as shape thereby mirroring each other. The longitudinal axes of the crista anterior and the crista lateralis were generally longer than the longitudinal axis of the crista posterior. At the free surface, the supporting cells firmly joined each other and linked the sensory cells in a compact reticular lamina. Each sensory cell was surrounded by three to five (usually four) supporting cells. Sensory cells with a larger free surface were often found in the central region of the crista. Those in the peripheral region of the crista had a smaller free surface, varying less in size. The supporting cells in the peripheral region were usually smaller than those in the central part. The sensory cells were found to be more concentrated in the peripheral region than in the central part of the crista. The transition from the central to the peripheral region was gradual and no obvious border was detected between the two regions. By focussing and thus adjusting the optical plane of the light microscope to about the upper one-third of the entire thickness of the surface specimen of the sensory epithelium, smaller and darker bottle necks of the type I sensory cells could easily be differentiated from larger and lighter cylinder

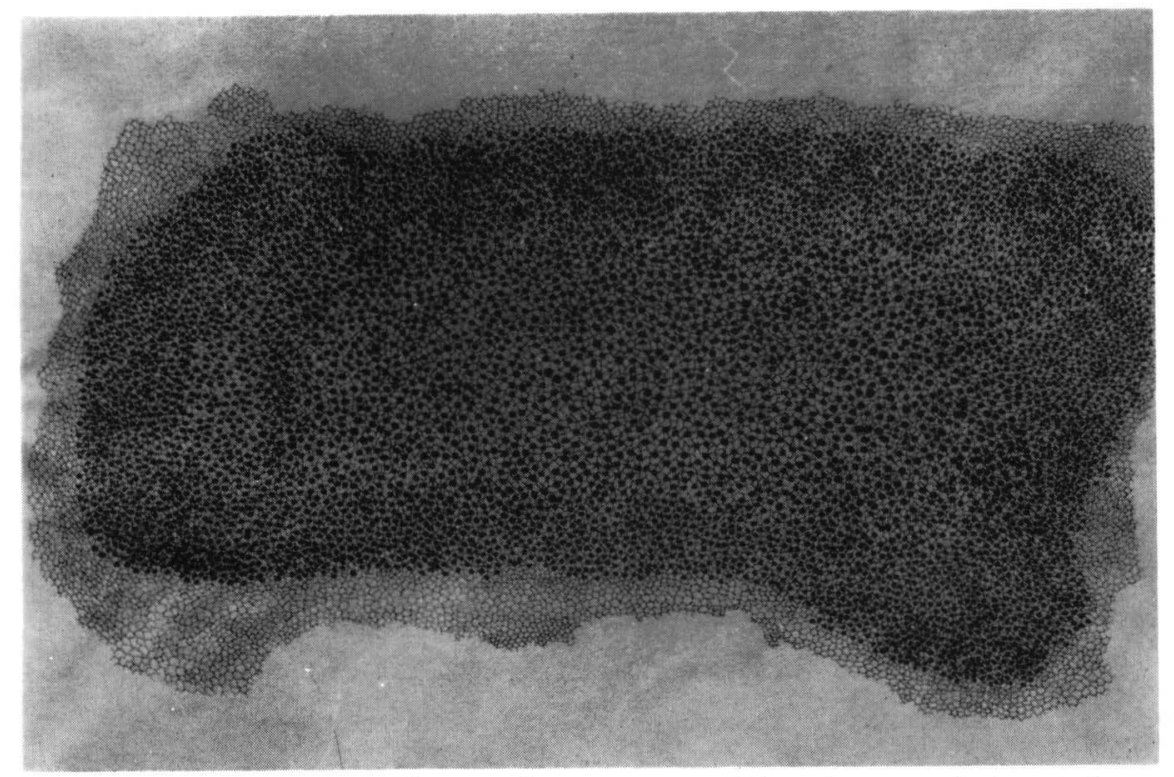

Figure. An exact copy of the surface structure of the crista ampullaris anterior of the right inner ear of the guinea pig after silver reaction method. The surface of the sensory cells is generally larger in the central region than in the peripheral area. The density of sensory cells is higher in the peripheral area than in the central region. Each dot is the surface of each sensory cell surrounded by several supporting cells in the sensory epithelium. 
rings of the type II sensory cells. No clear differences in the relative distibution of the two types of sensory cells of the central and peripheral regions of the crista could be detected. Type I cells included $45 \%$ and type II approx. $55 \%$. An exact statistical evaluation of type I and type II, however, was not done in the present study.

\section{DISCUSSION}

The surface area of the sensory epithelium of the crista of some experimental animals was outlined in part by Retzius (1884) ${ }^{15}$ and Iwata $(1924)^{7}$. Recently, Lindeman (196711, 196912,13,14) applied Engström's surface specimen technique, using the phase contrast microscope in making a quantitative analysis of the sensory epithelium of the crista. While in the present study the silver reaction methods (Katagiri et al 19689,10, Watanuki et al 196816, $1969^{17,18}$ ) proved to be of value in demonstrating a well contrasted surface structure of the vestibular sensory epithelium, the succinic dehydrogenase staining (Barka and Anderson $1963^{1}$ ) revealed only the sensory cells in the sensory epithelium of the crista ampullaris, which now could easily be counted. Since the sensory epithelium of the crista ampullaris follows the saddle shape of the crista, the specimen of the flattened overall surface revealed a shrunken surface area of the sensory epithelium with a pronounced cell density, especially in the peripheral region of the crista. As Lindeman (1969) 14 already demonstrated, the cells of the central and peripheral regions of the sensory epithelium could be clearly observed with respect to both size and density. As the periphery of the sensory epithelium is slightly elevated, the peripheral regions are shallow concave slopes which are covered only by a peripheral part of the cupula. The location of peripheral portions of the sensory epithelium may be related to the differences between the central and peripheral regions of the sensory epithelium. It is well known that two types of sensory cells, namely type I and type II, are found in the sensory epithelium of the vestibular sensory organs (Wersäll 195620). As Lindeman (1969) ${ }^{14}$ reported, no significant difference in the relative distribution of type I and the type II cells was detected over the entire crista. The distribution rate of the two types of cells, however, was different in the two studies. According to Lindeman (1969)14, type I cells included 55.7 to $65.8 \%$ and type II cells from 34.2 to $44.3 \%$. The present study revealed approx. $45 \%$ for type I cells and $55 \%$ for the type II cells. A detailed statistical evaluation of the two types of cells, however, was not performed in this study. Lindeman (1969) ${ }^{14}$ counted in three cristae an average of $5442(5445,5644$ and 5136) sensory cells in the crista anterior, 5688 (5622, 5690 and 5733) cells in the crista lateralis, and $5430(5916,5760$ and 4615 ) cells in the crista posterior. The result of the present study showed in 20 cristae of each, an average of 4581 sensory cells belonging to the crista anterior, 4587 cells to the crista lateralis and 4438 cells to the crista posterior. The sensory cells of the crista anterior and the crista lateraris in the same animal were almost equal in number in all examined animals, while those of the crista posterior were slightly less in nine of ten animals. In one animal, the sensory cells of the crista posterior were more often seen than those of the other two cristae. It is unknown whether or not this case is a rare exception in the guinea pig. As is 
Table. 1 Number of sensory cells in the sensory epithelia of the vestibular organs in guinea pigs.

\begin{tabular}{clllll}
\hline Animal & $\begin{array}{l}\text { Crista } \\
\text { anterior }\end{array}$ & $\begin{array}{l}\text { Crista } \\
\text { lateralis }\end{array}$ & $\begin{array}{l}\text { Crista } \\
\text { posterior }\end{array}$ & $\begin{array}{l}\text { Macula } \\
\text { sacculi }\end{array}$ & $\begin{array}{l}\text { Macula } \\
\text { utriculi }\end{array}$ \\
\hline 1. Right & 4211 & 4291 & 3777 & 6270 & 7110 \\
Left & 4210 & 4282 & 3689 & 6208 & 7112 \\
2. R. & 4503 & 4581 & 4428 & 6642 & 7913 \\
L. & 4492 & 4502 & 4409 & 6590 & 7908 \\
3. R. & 5093 & 4927 & 4891 & 6528 & 7012 \\
L. & 5010 & 5028 & 4902 & 6486 & 7088 \\
4. R. & 4196 & 4102 & 3982 & 5565 & 7873 \\
L. & 4188 & 4281 & 3905 & 5602 & 6794 \\
5. R. & 4820 & 4799 & 4682 & 6827 & 7755 \\
L. & 4902 & 4803 & 4659 & 6892 & 7691 \\
5. R. & 4582 & 4528 & 4505 & 6284 & 7307 \\
L. & 4599 & 4603 & 4527 & 6302 & 7209 \\
7. R. & 4483 & 4409 & 4194 & 6561 & 7003 \\
L. & 4496 & 4381 & 4208 & 6589 & 7098 \\
3. R. & 4071 & 4112 & 3855 & 6018 & 7098 \\
L. & 4122 & 4081 & 3791 & 5897 & 7111 \\
9. R. & 4139 & 4281 & 4621 & 6308 & 7235 \\
L. & 4092 & 4320 & 4580 & 6328 & 7311 \\
10. R. & 5767 & 5731 & 5518 & 7823 & 9011 \\
L. & 5740 & 5697 & 5627 & 7738 & 9131 \\
\hline
\end{tabular}

obvious from the Table, there are fairly large individual variations in number among the animials. The counts of the cells vary from 4071 to 5667 on the crista anterior, 4081 to 5731 on the crista lateralis and 3689 to 5627 on the crista posterior. If we compare the numerical data of the present study with that of Lindeman, only one animal in our study had a sensory cell count higher than the average number in Lindeman's. It was also found that the sensory cells in our study were relatively less in number, namely, the average number of on the crista anterior, lateralis and posterior in our study was $84.1 \%, 84.2 \%$ and $78.0 \%$ respectively, over that of Lindeman's. The difference in the results of these two studies may be explained as follows: I) In the present study, succinic dehydrogenase staining was applied which revealed only the sensory cells in the sensory epithelium. It is possible, however, that some inactive sensory cells remained unstained; and 2) The examined animals could have been of a different strain. In any event, fairly numerous variations are seen in the number of sensory cells in the guinea pig.

\section{REFERENCES}

1) Barka, T. \& Anderson, P.J.: Histochemistry. Harper and Row, New York, 1963.

2) Burlet H.M. de, de HaAs J.H.: Die Stellung der Maculae acusticae im Madasusschädel. $Z$ Anat u Entw gesch 71 : 233-239, 1924.

3) Burlet, H.M. de, \& Hoffmann, J.M.: Beitrag zur Kenntnis der Maculae bei Saugetieren. Arch Ohr Nas u Kehlk Heilk 120: 233-255, 1929.

4) Engström, H. \& Ades H.W. Hawkins, J. E. JR.: Cytoarchitecture of the organ of Corti. 
Acta Oto-laryng. Suppl. 188: 92-99, 1964.

5) Engström, H. \& Ades H.W. Andersson, A.: Structural pattern of the organ of Corti. Stockholm, Almquist and Wiksell, 1966.

6) Hawkins, J.E. JR. \& Johnsson, L-G: Light microscopic observations of the inner ear in man and monkey. Ann. Otol. 77: 608-629, 1968.

7) IwATA, N.: Über das Labyrinth der Pledermaus mit besonderer Berücksichtigung des statischen Apparatus. Aichi J Exp Med 2: 42-112, 1924.

8) Johnsson, L-G \& HAwkins, J.E. JR.: A direct approach to cochlear anatomy and pathology in man. Arch Otolaryng. 85: 599-613, 1967.

9) Katagiri, S., Kawamoto, K. \& Watanuki, K.: Some surface views of the stria vascularis and its adjacent areas. Acta Oto-laryng. 66: 386-398, 1968.

10) Katagiri, S., Kawamoto, K., Hori, K., et al: Some surface views of the inner ear by light microscopy. Acta Oto-laryng. 66: 477-507, 1968.

11) Lindeman, H.H.: Cellular pattern and nerve supply of the vestibular sensory epithelia. Acta Oto-laryng. Suppl. 224: 86-95, 1967.

12) Lindeman, H.H.: Regional differences in structure of the vestibular sensory regions. $J$. Laryng. 83: 1-17, 1969.

13) Lindeman, H.H.: Regional differences in sensitivity of the vestibular sensory epithelia to ototoxic antibiotics. Acta Oto-laryng. 67: 177-189, 1969.

14) Lindeman, H.H.: Studies on the morphology of the sensory regions of the vestibular apparatus. Ergebn Anat u Entw gesch 42: 1-113, 1969.

15) Retzius, G.: Das Gehörorgan der Wirbeltiere. Samson and Wallin, Stockholm, 1884.

16) Watanuki, K.: Some morphological observations of Reissner's membrane. Acta Oto-laryng. 66: 40-48, 1968.

17) Watanuki, K., Kawamoto, K. \& KatagiRI, S.: Repair pattern of the reticular lamina of the organ of Corti after hair cell loss. Ann. Otol. 78: 1210-1219, 1969.

18) Watanuki, K. \& Meyer zum Gottesberge, A.: Light microscopic observations of the sensory epithelium of the crista ampuularis in the guinea pig. Ann. Otol. 80: 450-454, 1971 .

19) Werner, C.F.: Differenzierung der Maculae im Labyrinth, insbesondere bei Säugetieren. Z Anat Entw gesch 99: 696-709, 1933.

20) WERSÄLL, J.: Studies on the structure and innervation of the sensory epithelium of the cristae ampullares in the guinea pig. Acta Oto-laryng. Suppl. 126: 1-85, 1956.

(Received September 6, 1972) 